Article history: Submitted 8 April 2020; Accepted 21 May 2020; Available online 1 June 2020

\title{
Dinamika Hukum Waris Adat di Masyarakat Bali Pada Masa Sekarang
}

\author{
Dinta Febriawanti dan Intan Apriyanti Mansur \\ dintafebri38@gmail.com \\ Universitas Airlangga
}

\begin{abstract}
Keywords: $\quad$ Abstract
Customary In Indonesia there are three inheritance laws, namely customary inheritance law, Islamic Inheritance Law; inheritance law, and BW inheritance law. Customary inheritance law is inseparable Balinese Customary from the existence of legal pluralism in force in Indonesia where each region has different Inheritance Law; customs. In this article, we will discuss the customary inheritance law, especially in Inheritance Balinese society. Over time, the customary inheritance law in Bali is still ongoing and maintained from the previous generation to the next generation to be preserved and applied. However, in practice there are sometimes some problems regarding the distribution of inheritance given or left by the testator. The reason is because it feels unfair about the portion of the assets given considering that in Bali the implementation of customary law and customary inheritance law are still very thick. These problems led to the resolution of disputes in court. The problem in the distribution of assets legally in the traditional inheritance in Bali in this article will be discussed and related to the current situation where at this time the era has advanced and there are developments in resolving cases of customary inheritance disputes in court.
\end{abstract}

Kata Kunci: Hukum Waris Adat; Hukum Waris Adat Bali; Waris.

\begin{abstract}
Abstrak
Di Indonesia terdapat tiga hukum waris, yaitu hukum waris adat, hukum waris Islam, dan hukum waris BW. Hukum waris adat tidak terlepas dari adanya pluralisme hukum yang berlaku di Indonesia di mana setiap daerah memiliki adat yang berbeda-beda. Dalam artikel ini yang akan di bahas yaitu hukum waris adat, khususnya di masyarakat Bali. Seiring berjalannya waktu, hukum waris adat di Bali masih berlangsung dan dipertahankan dari generasi sebelumnya hingga ke generasi selanjutnya untuk dilestarikan dan diterapkan. Akan tetapi dalam pelaksanaannya terkadang ada beberapa masalah mengenai pembagian harta waris yang diberikan atau ditinggalkan oleh si pewaris. Penyebabnya yaitu karena dirasanya kurang adil mengenai bagian harta yang diberikan mengingat bahwa di Bali pelaksanaan hukum adat maupun hukum waris adatnya yang masih sangat kental. Permasalahan tersebut berujung pada penyelesaian sengketa di pengadilan. Adanya permasalahan di dalam pembagian harta secara hukum waris adat di Bali tersebut dalam artikel ini akan dibahas dan dikaitkan dengan keadaan zaman sekarang di mana pada saat ini zaman sudah maju dan terdapat perkembangan dalam menyelesaikan perkara sengketa waris adat di pengadilan.
\end{abstract}

Copyright (C) 2020 Universitas Airlangga

\section{Pendahuluan}

Indonesia merupakan negara yang sangat luas. Indonesia memiliki ragam budaya, suku, bahasa, agama, juga memiliki banyak sekali pulau, baik yang besar maupun kecil. Bangsa Indonesia sebagai bangsa yang bermartabat mempunyai 
"budaya" berupa "adat istiadat" yang mencerminkan dari pada kepribadian sesuatu bangsa Indonesia, selanjutnya menjadi sumber bagi sistem hukum adat. ${ }^{1}$ Di setiap daerah tentunya memiliki tata cara kebiasaan atau adat masing-masing yang khas di mana terdapat hukum adat dan masyarakat adat. Bahkan beberapa daerah pada saat ini masih menerapkan hukum adatnya. Penerapan tersebut tentunya dengan tujuan bahwa agar keberadaannya atau eksistensinya tetap bertahan di era sekarang.

Hukum adat menurut Soepomo didefinisikan sebagai hukum nonstatutair yang sebagian besar merupakan hukum kebiasaan dan sebagian kecil merupakan hukum islam. Hukum adat pun meliputi hukum yang berdasarkan keputusan-keputusan hakim yang berisi asas-asas hukum dalam lingkungan, dalam memutuskan perkara, hukum adat berurat berakar pada kebudayaan tradisional. ${ }^{2}$ Hukum adat merupakan hukum asli bangsa Indonesia. Hukum waris adat meliputi norma-norma hukum yang menetapkan harta kekayaan baik yang materiil maupun yang immaterial yang manakah dari seseorang yang dapat diserahkan kepada keturunannya serta yang sekaligus juga mengatur saat, cara, dan proses peralihannya. ${ }^{3}$ Proses peralihan itu sendiri sesungguhnya sudah dapat dimulai semasa pemilik harta kekayaan itu sendiri masih hidup, serta proses itu selanjutnya berjalan terus hingga keturunannya itu masingmasing menjadi keluarga-keluarga baru yang berdiri sendiri-sendiri. ${ }^{4} \mathrm{Di}$ Indonesia sendiri, dewasa ini, telah mengarah pada sistem parental atau bilateral. Namun demikian, masih banyak juga suku-suku masyarakat pedesaan yang tetap mempertahankan prinsip keturunan dan kekerabatan patrilineal maupun matrilineal. ${ }^{5}$ Sehingga dalam hal ini dapat dikatakan bahwa sistem hukum waris adat di Indonesia tidak terlepas dari adanya sistem kekeluargaan atau sistem

\footnotetext{
Soerojo Wignjodipoero, Pengantar Dan Asas-Asas Hukum Adat (Gunung Agung 1995).[13].

R.Soepomo, Bab-Bab Tentang Hukum Adat (Pradnya Paramita 1981).[42].

Soerojo Wignjodipoero (n 1)., Op. Cit.161].

4 ibid.[161].

5 Haniam Maria, 'Mengenal Sistem Kekerabatan Patrilineal Dan Matrilineal' (Kompasiana, 2014)<https:/ / www.kompasiana.com/amp/honey95t/mengenal-sistem-kekerabatan-patrilineal-dan-matrilineal_54fd224fa33311043d50f8b7> accessed 11 April 2020.
} 
kekerabatan. Hal ini dikarenakan eratnya hubungan di antara hukum waris adat dengan hukum adat.

Di masyarakat Bali, pembagian harta waris masih sangat berkaitan dengan sistem pewarisan adatnya. Ketika si pewaris meninggal terkadang harta pewaris tersebut belum dibagikan kepada keturunannya. Dalam beberapa hal, seseorang terkadang membagi harta waris secara kekeluargaan. Pembagian harta warisnya berdasarkan hukum waris adat Bali. Akan tetapi ketika pembagian tersebut dilaksanakan, terkadang ada seseorang yang tidak terima dengan pembagian waris tersebut karena dirasa kurang adil atau tidak sesuai dengan yang diharapkan. Di sisi lain, ketika pewaris telah meninggal, akan tetapi harta waris belum dibagikan kepada keturunannya sehingga menimbulkan sengketa. Akibat dari adanya sengketa tersebut penyelesaiannya yaitu dengan dibawa ke pengadilan oleh para ahli waris. Dan dengan di bawanya sengketa hukum waris tersebut ke pengadilan, tentunya hal ini juga mempengaruhi jumlah harta waris yang akan dibagikan atau diperoleh.

Salah satu kasus sengketa waris adat yang belum lama ini yaitu dalam Putusan Mahkamah Agung Nomor 257 K/Pdt/2019. Kasus tersebut terjadi di Bali, tepatnya yang disengketakan yaitu tanah seluas 4.150 meter persegi yang terletak di Desa Timuhan, Kecamatan Bajarangkan, Kabupaten Klungkung. Penggugat dalam kasus ini menuntut agar tanah tersebut dinyatakan oleh hakim sebagai hak milik atas namanya karena ialah yang telah mengurus dan membayar pajak tanah tersebut. Sedangkan para kerabat-kerabatnya (para tergugat) ikut mengerjakan tanah setelah pewaris meninggal karena mereka merasa berhak juga atas tanah tersebut dimana masih dalam satu garis keturunan yang sama. Tanah tersebut belum dialihkan atau dioperkan kepada ahli waris karena pewaris telah meninggal dunia terlebih dahulu.

Di dalam kasus ini, baik penggugat maupun para tergugat merupakan sama-sama ahli waris dari pewaris. Dalam putusannya, Majelis Hakim berpendapat bahwa alasan yang dikemukakan para tergugat dapat diterima dan tidak bertentangan dengan hukum sehingga kemudian diputuskan bahwa harta 
warisan peninggalan pewaris yang berupa sebidang tanah seluas 4.150 meter persegi tersebut harus di bagi kepada ahli waris lainnya. Karena pewaris memiliki 6 orang anak laki-laki, maka tanah tersebut haruslah dibagi kepada 6 orang anak tersebut dengan bagian 1/6 (satu per enam) bagian atau 691,6 meter persegi untuk setiap anak, sehingga para tergugat berhak juga mendapatkan 5/6 bagian 3.458 meter persegi atas tanah yang ditinggalkan oleh pewaris tersebut.

Penggugat tetap berusaha mengajukan upaya hukum banding hingga kasasi. Namun, karena tidak ditemukan fakta yang baru dan bukti yang kurang yang dimiliki oleh pihak penggugat untuk membuktikan kepemilikan atas tanah tersebut, dalam upaya hukum banding dan kasasi, Majelis Hakim berpendapat bahwa putusan pengadilan yang sebelumnya telah benar dalam menerapkan hukum. Yang menjadi pertimbangan Majelis Hakim antara lain fakta bahwa SPPT yang menjadi bukti penggugat tidak dapat dijadikan sebagai bukti kepemilikan hak, melainkan hanya sebagai pemberitahuan kewajiban kepada wajib pajak untuk membayar Pajak Bumi dan Bangunan (PBB). Memiliki SPPT di sini bukan berarti memiliki hak atas tanah yang tercantum di dalam SPPT tersebut. Berdasarkan Surat Tanda Pendaftaran Sementara Tanah Milik Indonesia Nomor Buku Pendaftaran Huruf C.79 tertulis $d t$ yang berarti tanah tersebut adalah duwe tengah (milik bersama) para ahli waris. Dalam hal ini tanah tersebut tidak pernah diberikan kepada Penggugat secara pribadi. Selain itu fakta yang menunjukkan bahwa baik penggugat maupun para tergugat merupakan ahli waris yang sah dari Pewaris sehingga membuat Majelis Hakim kemudian memutuskan untuk menguatkan amar putusan-putusan yang sebelumnya, yaitu Putusan Nomor 76/ Pdt.G/2017/PN Srp tanggal 3 April 2018 dan Putusan Pengadilan Tinggi Bali yaitu Putusan Nomor 86/Pdt/2018/PT DPS tanggal 7 Agustus 2018.

\section{Sistem Hukum Kekerabatan di Bali}

Hukum waris adat memuat tiga unsur pokok, yaitu:

1. Mengenai subyek hukum waris, yaitu siapa yang menjadi pewaris dan siapa yang menjadi ahli waris; 
2. Mengenai kapan suatu warisan itu dialihkan dan bagaimana cara yang dilakukan dalam pengalihan harta waris tersebut serta bagaimana bagian masing-masing ahli waris;

3. Mengenai obyek hukum waris itu sendiri, yaitu tentang harta apa saja yang dinamakan harta warisan, serta apakah harta-harta tersebut semua dapat diwariskan. ${ }^{6}$

Prinsip-prinsip garis keturunan terutama berpengaruh terhadap penetapan ahli waris maupun bagian harta peninggalan yang diwariskan (baik yang materiil maupun yang immaterial). ${ }^{7}$ Menurut Hazairin, terdapat tiga prinsip pokok garis kekerabatan, antara lain:

1. Patrilineal

Yang menimbulkan kesatuan-kesatuan kekeluargaan yang besar-besar, seperti clan, marga, di mana setiap orang itu selalu menghubungkan dirinya hanya kepada ayahnya. Oleh karena itu, termasuk ke dalam clan ayahnya, yakni dalam sistem patrilineal murni seperti di tanah Batak atau di mana setiap orang itu menghubungkan dirinya kepada ayahnya atau kepada maknya, tergantung kepada bentuk perkawinan orang tuanya itu, dan karena itu termasuk ke dalam clan ayahnya ataupun ke dalam clan ibunya yakni -dalam sistem patrilineal yang beralih-alih, seperti di Lampung dan Rejang;

2. Matrilineal

Yang juga menimbulkan kesatuan-kesatuan kekeluargaan yang besarbesar, seperti clan, suku, di mana setiap orang itu selalu menghubungkan dirinya hanya kepada maknya atau ibunya, dan karena itu termasuk ke dalam clan, suku, maknya itu; dan

3. Bilateral/Parental

Yang mungkin menimbulkan kesatuan-kesatuan kekeluargaan yang besar-besar, seperti tribe, rumpun, di mana setiap orang itu menghubungkan

6 Evi Risna Yanti, 'Pembagian Waris Menurut Hukum Adat Jawa' (HukumOnline.Com, 2012) <https://m.hukumonline.com/klinik/detail/ulasan/lt4fcc4bee2ae6f/berhak-atau-tidaknyamendapatkan-waris-dari-orang-tua-tugas-hk-waris-adat> accessed 13 April 2020.

7 Soerjono Soekanto, Hukum Adat Indonesia (Rajawali Pers 2010).[259]. 
dirinya dalam hal keturunan baik kepada maknya maupun kepada ayahnya. $^{8}$

Dari pendapat Hazairin tersebut dapat dikatakan bahwa dalam sistem kekerabatan patrilineal prinsip keturunannya yaitu mengikuti garis keturunan ayah. Selain yang diungkapkan di atas, prinsip ini juga diterapkan di Bali. Dalam hal ini hanya anak laki-laki saja yang berhak mewaris. Sedangkan prinsip matrilineal yaitu prinsip keturunan yang mengikuti dari garis keturunan ibu. Sistem hukum warisan atas dasar kekerabatan ini sudah berlaku sejak dahulu kala, sebelum masuknya ajaran-ajaran agama di Indonesia, seperti Hindu, Islam, dan Kristen. ${ }^{9}$ Sistem ini diterapkan di Minangkabau. Di dalam sistem ini, yang berhak untuk mewaris yaitu anak perempuan saja.

Di samping sistem kekerabatan di atas, hukum waris adat mengenal adanya tiga sistem pewarisan, yaitu: ${ }^{10}$

\section{Sistem Pewarisan Kolektif}

Sistem Pewarisan Kolektif yaitu sistem kewarisan di mana para ahli waris mewarisi harta peninggalan pewaris secara bersama-sama (kolektif). Hal ini terjadi karena harta peninggalan yang diwarisi itu merupakan harta turun temurun dan tidak dapat dibagi pemilikannya kepada masing-masing ahli waris. Dengan kata lain, harta peninggalan itu tidak dapat dimiliki oleh seorang saja, melainkan harus dimiliki secara bersama-sama, misalnya: harta pusaka di Minangkabau, rumah gadang yang merupakan tanah marga, tidak dapat dijual namun dapat digadaikan, tanah di Semenanjung Hitu (Ambon).

\section{Sistem pewarisan mayorat}

Sistem pewarisan mayorat adalah sistem kewarisan dimana harta peninggalan pewaris hanya diwarisi oleh seorang anak tertua, sama dengan pewarisan kolektif namun diwaris oleh anak tertua. Sistem pewarisan mayorat ini dibagi atas dua bagian, yaitu: (a) mayorat laki-laki, yaitu apabila anak laki-

8 Hazairin, Tujuh Serangkai Tentang Hukum (Bina Aksara 1985).[11].

9 H. Hilman Hadikusuma, Hukum Waris Adat (Citra Aditya Bakti 1993).[23].

10 Sri Hajati et.al, Buku Ajar Hukum Waris (Adat, Islam Dan Burgerlijk Wetboek) (Airlangga University Press 2018).[17-18]. 
laki tertua (keturunan laki-laki) yang waris tunggal dari si pewaris, dengan catatan anak tersebut harus menghidupi orang tua dan adik-adiknya, misalnya pada masyarakat Lampung dan Bali' b). mayorat perrempuan, yaitu apabila anak perempuan tertua yang merupakan ahli waris tunggal dari si pewaris, dengan catatan anak tersebut harus menghidupi orang tua dan adik-adiknya, misalnya pada masyarakat suku Semendo di Sumatera Selatan, suku Dayak Landak dan Suku Dayak Tayan di Kalimantan Barat (anak pangkalan).

\section{Sistem Pewarisan Individual}

Berdasarkan sistem ini, maka setiap ahli waris mendapatkan atau memilki harta warisan menurut bagiannya masing-masing. Pada umumnya sistem ini dijalankan di masyarakat yang menganut sisten kemasyarakatan parental atau bilateral seperti masyarakat Jawa.

Atau dengan kata lain, di dalam sistem pembagian harta warisan ini, harta peninggalan dapat dibagi-bagikan dari pemiliknya atau pewaris kepada ahli warisnya dan dimiliki secara pribadi. ${ }^{11}$

Dari tiga sistem pewarisan di atas, diketahui bahwa dalam hukum waris adat Bali berlaku sistem pewarisan mayorat yaitu sistem kewarisan dimana harta peninggalan pewaris hanya diwarisi oleh seorang anak tertua, sama dengan pewarisan kolektif namun diwaris oleh anak tertua. Sistem pewarisan mayorat ini dibagi atas dua bagian, yaitu: (a) mayorat laki-laki, yaitu apabila anak laki-laki tertua (keturunan laki-laki) yang waris tunggal dari si pewaris, dengan catatan anak tersebut harus menghidupi orang tua dan adik-adiknya. ${ }^{12}$ Dalam prinsip ini yang mendapat harta warisan hanya anak yang tertua saja, sedangkan saudaranya yang lain dalam hal ini tidak mendapatkan harta si pewaris. Akan tetapi, meskipun anak tertualah yang hanya mendapatkan harta tersebut, ia memiliki kewajiban atau tanggung jawab bahwa ia harus menghidupi orang tua dan saudaranya yang lebih muda atau adik-adiknya.

\footnotetext{
11 Komari, 'Eksistensi Hukum Waris Di Indonesia: Antara Adat Dan Syariat' (2015) 17 AsySyari'ah.[165].

12 ibid.[165].
} 
Di masyarakat Bali, dalam hal harta (obyek warisan) dapat dibedakan menjadi dua, yaitu harta pusaka (bernilai magis-religius) dan/atau harta benda (yang bernilai ekonomis). Sedangkan dalam ahli waris (subyek warisan) juga dibedakan menjadi dua, yaitu ahli ahli waris predana dan/atau ahli waris purusa. Kenapa ahli waris predana, bukan perempuan? Karena perempuan tidak selalu predana dan sebaliknya, dan purusa tidak selalu laki-laki dan sebaliknya. ${ }^{13}$

Dalam Putusan Mahkamah Agung Nomor 257 K/Pdt/2019 dinyatakan bahwa permohonan kasasi ditolak dan menyatakan penggugat dan tergugat berhak mendapatkan bagian harta waris yang berupa tanah tersebut. Hal ini dengan pertimbangan bahwa bukti yang diajukan oleh penggugat yang berupa SPPT tidak dapat dijadikan bukti kepemilikan hak, melainkan hanya sebagai pemberitahuan kewajiban kepada wajib pajak untuk membayar PBB sehingga memiliki SPPT bukan berarti tanda bahwa memiliki hak atas tanah yang tercantum dalam SPPT tersebut. Kemudian berdasarkan Surat Tanda Pendaftaran Sementara Tanah Milik Indonesia, Nomor Buku Pendaftaran Huruf C.17 tertulis $d t$ yang berarti "duwe tengah" (milik bersama) para ahli waris. Sehingga dapat dikatakan bahwa tanah tersebut tidak pernah diberikan kepada penggugat secara pribadi. Selain itu bahwa sebenarnya penggugat dan tergugat masih merupakan dalam satu garis keturunan yang sama dan ahli waris yang sah. Sehingga tanah tersebut dibagi sesuai dengan jumlah ahli waris. Akan tetapi karena ada beberapa ahli waris yang telah meninggal, maka bagian harta waris tersebut digantikan oleh keturunannya.

Dari isi putusan Mahkamah Agung tersebut di atas, dalam hal ini pembagian harta warisnya dapat dikatakan telah dilakukan dengan mengikuti cara sistem pewarisan individual. Di dalam sistem ini, setiap ahli waris mendapatkan atau memiliki hartawarisan menurutbagiannya masing-masing. Dan sistem pembagian harta warisan dalam masyarakat ini adalah individual yang artinya bahwa harta peninggalan dapat dibagi-bagikan dari pemiliknya atau pewaris kepada

${ }^{13}$ I Gede Surata, 'Kedudukan Ahli Waris Predana Menurut Hukum Adat Bali Hubungannya Dengan Hak Atas Tanah Terkait Dengan Pesamuan Agung III Tahun 2010’ (2019) 2 Kertha Widya Jurnal Hukum.[20]. 
ahli warisnya dan dimiliki secara pribadi. Pada umumnya sistem ini dijalankan di masyarakat yang menganut sistem kemasyarakatan parental atau bilateral seperti pada masyarakat Jawa. ${ }^{14}$ Selain mengikuti sistem pewarisan individual, dalam pembagian warisan di putusan tersebut masih tetap menggunakan sistem patrilineal yaitu bahwa yang mewaris harta si pewaris hanya anak lakilaki saja. Padahal, pewarisan menurut hukum adat bali tidak identik dengan membagi harta peninggalan (warisan) orang tua dan leluhur (pewaris) oleh ahli waris, melainkan mengandung makna pelestarian, pengurusan dan penerusan swadharma (tanggung jawab) dan swadikara (hak) terhadap peninggalan pewaris dalam berbagai wujud dan sifatnya. ${ }^{15}$

Selain Putusan Mahkamah di atas, terdapat beberapa Putusan Mahkamah Agung lainnya yang juga isi putusannya terdapat perubahan dalam menetapkan harta warisan di masyarakat adat. Beberapa putusan Mahkamah Agung tersebut antara lain seperti Putusan Mahkamah Agung Republik Indonesia No. 179 K/ SIP/1961 tanggal 23 Oktober 1961 yang di dalamnya memuat kaidah hukum, Mahkamah Agung mengganggap sebagai hukum yang hidup di seluruh Indonesia, juga di tanah Karo, bahwa anak perempuan dan anak laki-laki dari seorang peninggal warisan bersama-sama berhak atas harta warisan dalam arti bahwa bagian anak laki-laki adalah sama dengan bagian anak perempuan; Putusan Mahkamah Agung Republik Indonesia No. 415 K/SIP/1970 tanggal 30 Juni 1970 yang memuat kaidah hukum, hukum adat di daerah Tapanuli juga telah berkembang kearah pemberian hak yang sama kepada anak perempuan seperti anak laki-laki, perkembangan mana sudah diperkuat pula dengan suatu yurisprudensi tetap mengenai hukum waris di daerah tersebut; Putusan Mahkamah agung republik Indonesia No. 707 K/SIP/1973 tangggal 18 Maret 1976 yang memuat kaidah hukum, pembagian warisan dalam perkara ini sekarang harus menurut hukum yang mengakui hak wanita sama dengan hak laki-laki

\footnotetext{
${ }^{14}$ Oemar Moechthar, Perkembangan Hukum Waris: Praktik Penyelesaian Sengketa Kewarisan Di Indonesia (Prenadamedia Group 2019).[199]. 2017).

${ }^{15}$ Wayan P. Windia, 'Sistem Pewarisan Menurut Hukum Adat Bali' (Universitas Udayana
} 
dalam hukum warisan (peninggalan warisan ialah ibu Penggugat asal/ibu Tergugat asal meninggal pada zaman Jepang); Putusan MARI No. 997 K/SIP/1972 yang memuat kaidah hukum, anak angkat berhak atas harta bawaan dari orang tua angkatnya. Sikap ini dikuatkan oleh putusan No. 1002 K/ Sip/1976 yang mengatakan janda dan anak angkat berhak mewarisi harta gono gini sedangkan harta gawaan kembali ke asal. ${ }^{16}$

Selain itu, terdapat juga Putusan Mahkamah Agung Nomor 100/K/ SIP/1967sebenarnya tidak hanya terkait dengan anak perempuan tetapi juga janda dari pewaris karena keduanya menjadi tergugat dalam perkara ini. Perkara dalam putusan ini merupakan sengketa waris antara Tangsi Bukit (anak laki-laki pewaris) melawan ibu tirinya, Pengidahen boru Meliala, dan saudara perempuannya, Muli boru Bukit. Penggugat berpendapat bahwa yang berhak mewaris hanya anak laki-laki, sedangkan harta warisan telah dijual oleh Pengidahen boru Meliala. Pengadilan Negeri Kabanjahe sebelumnya menyatakan gugatan Tangsi Bukit tidak dapat diterima. Tangsi Bukit mengajukan banding ke Pengadilan Tinggi Medan. Pengadilan Tinggi Medan membatalkan putusan sebelumnya tetapi hanya menetapkan 1/6 bagian dari harta untuk Tangsi Bukit yang tidak puas kemudian mengajukan kasasi ke Mahkamah Agung. Namun Mahkamah Agung berpendapat bahwa pertumbuhan masyarakat telah mengarah ke arah persamaan kedudukan antara laki-laki dan perempuan. Selain itu, penetapan janda sebagai ahli waris telah menjadi yurisprudensi yang dianut oleh Mahkamah Agung,; Putusan Mahkamah Agung No. 1589 K/Sip/1974 Putusan ini mengacu pada yurisprudensi Mahkamah Agung terhadap anak perempuan di Tapanuli dalam pewarisan. Berdasarkan putusan ini, anak perempuan merupakan ahli waris. Mahkamah Agung mempertimbangkan bahwa masyarakat Sasak adalah masyarakat patrilineal, tetapi sesuai dengan perkembangan zaman juga mengarah pada garis ayah maupun ibu; Putusan Pengadilan Negeri Kabanjahe No. 23/Pdt.G/2009/

${ }^{16}$ Hulman Panjaitan, 'Keberadaan Hukum Adat Dalam Yurisprudensi' (2016) 2 Jurnal Hukum tô-râ.[417-418].

${ }^{17}$ Victor Imanuel W. Nalle, 'Pembaharuan Hukum Waris Adat Dalam Putusan Pengadilan' (2018) 30 Mimbar Hukumkum..[438-439]. 
PN.Kbj Pertimbangan hukum dalam putusan ini menyatakan bahwa hukum waris Indonesia mengakui pembagian yang sama di antara semua ahli waris tanpa membedekan jenis kelamin dan urutan kelahiran; Putusan Pengadilan Negeri Medan No. 397/PDT.G/2012/PN.MDN Putusan ini menyatakan harta warisan, yaitu rumah milik pewaris, dibagi secara merata kepada seluruh ahli wali (anak laki-laki dan perempuan). Putusan ini menggunakan Putusan Mahkamah Agung No. 179/K/Sip/1961 dalam pertimbangan hukumnya; Putusan pengadilan Tinggi Medan No. 360/PDT/2015PT-MDN. Putusan ini menguatkan dan memperbaiki Putusan pengadilan Negeri Medan No. 1333/Pdt.G/2014/PN.MDN. Putusan ini menetapkan setiap orang dari enam orang ahli waris menerima $1 / 6$ bagian atas harta warisan. ${ }^{18}$

Jika sengketa di pembagian harta warisnya dilakukan secara hukum waris adat, maka seharusnya hukum pewarisan yang berlaku yaitu sistem pewarisan secara mayorat seperti yang telah dipaparkan diatas. Akan tetapi jika ditelusri lagi, di dalam putusan Mahkamah Agung tersebut sistem pambagian harta warisan yang berlaku yaitu sistem pewarisan secara individual. Dalam hal ini, setiap ahli waris mendapatkan bagiannya masing-masing. Lalu dari putusan tersebut dapat diketahui bahwa pembagian waris tetap dilakukan dalam sistem kekerabatan patrilineal akan tetapi dengan sistem pewarisan secara individual di mana yang berhak mewaris yaitu hanya anak laki-laki saja tetapi dari setiap anak laki-laki tersebut mendapatkan bagiannya masing-masing.

Dari adanya Putusan Nomor 257 K/Pdt/2019 dan beberapa Putusan tersebut di atas dapat dikatakan bahwa telah ada perkembangan di bidang pembagian harta waris menggunakan hukum waris adat. Dengan adanya Putusan Mahkamah Agung Nomor 257 K/Pdt/ 2019 telah menunjukkan bahwa hukum waris adat di Bali dalam perkara tersebut telah mengalami pergeseran dengan seiring berjalannya waktu pada era sekarang ini dimana seharusnya berlaku sistem mayorat yang dilakukan dalam pembagian warisnya, akan tetapi hakim dalam menyelesaikan

18 ibid.[441]. 
sengketa waris adat itu memutuskan bahwa sistem pembagian waris tersebut dilakukan dengan sistem individual di mana setiap ahli waris mendapatkan bagian masing-masing. Hal itu tentunya dengan mempertimbangan fakta-fakta yang telah dipaparkan di atas serta dalam hal ini terdapat juga pendapat penulis bahwa pertimbangan mengenai pembagian harta waris tersebut dilakukan dengan cara sistem kekerabatan dengan patrilineal dan sistem pewarisan secara individual agar di kemudian hari ahli waris yang menerima harta warisan tidak memperebutkan lagi tentang harta yang ditinggalkan oleh si pewaris.

Selain alasan di atas, dalam hal ini menurut penulis, hakim memutuskan demikian karena pada dasarnya di dalam keluarga tersebut sama-sama berhak mendapatkan harta warisan dari si pewaris dan juga pada zaman sekarang ini meskipun pembagian harta waris dengan menggunakan hukum waris adat masih ada eksistensinya, hakim memutuskan pembagian harta warisan secara adil di mana dalam hal ini maksudnya adalah pembagiannya secara merata karena terdapat beberapa sistem pembagian harta waris yang sudah kurang relevan lagi untuk diterapkan. Sehingga dengan adanya putusan-putusan hakim tersebut yang bertambah di beberapa tahun ke depan ini dapat dikatakan bahwa penerapan hukum waris secara adat telah mengalami perubahan.

\section{Kesimpulan}

Dalam hukum waris di Indonesia, terdapat tiga Hukum waris. Salah satunya yaitu hukum waris adat. Hukum waris adat di Bali masih diterapkan sampai sekarang. Penerapannya masih dipengaruhi oleh sistem kekerabatan yang masih melekat atau erat di Bali. Akan tetapi, seiring berjalannya waktu, pembagian harta waris berdasarkan hukum waris adat yang dahulunya sering dilakukan dengan kekeluargaan beserta dengan hukum waris adat yang berlaku, sistem pewarisan adat di Bali tersebut pada masa sekarang terdapat kelonggaran atau pergeseran dalam pelaksanaannya di mana ketika pembagian harta waris tersebut penyelesaiannya dilakukan di pengadilan. Menurut penulis, hal ini karena dalam memutuskan sengketa waris adat tersebut, majelis hakim yang memutus, 
mempertimbangkan mengenai pembagian waris itu dengan membaginya secara adil agar suatu hari nanti pembagian harta waris tersebut tidak terjadi sengketa kembali selain memperhatikan fakta-fakta hukumnya yang ada di pengadilan. Dengan adanya putusan-putusan hakim ini tentunya juga berdampak kepada hukum waris adat di Bali, bahwa hukum waris adat tersebut akan mengalami perkembangan seiring dengan berkembangnya zaman.

\section{Daftar Bacaan}

\section{Buku}

H. Hilman Hadikusuma, Hukum Waris Adat (Citra Aditya Bakti 1993).

Hazairin, Tujuh Serangkai Tentang Hukum (Bina Aksara 1985).

Oemar Moechthar, Perkembangan Hukum Waris: Praktik Penyelesaian Sengketa Kewarisan Di Indonesia (Prenadamedia Group 2019).

R.Soepomo, Bab-Bab Tentang Hukum Adat (Pradnya Paramita 1981).

Soerjono Soekanto, Hukum Adat Indonesia (Rajawali Pers 2010).

Soerojo Wignjodipoero, Pengantar Dan Asas-Asas Hukum Adat (Gunung Agung 1995).

Sri Hajati et. a., Buku Ajar Hukum Waris (Adat, Islam Dan Burgerlijk Wetboek) (Airlangga University Press 2018).

\section{Jurnal}

Hulman Panjaitan, 'Keberadaan Hukum Adat Dalam Yurisprudensi' (2016) 2 Jurnal Hukum tô-râ.

I Gede Surata, 'Kedudukan Ahli Waris Predana Menurut Hukum Adat Bali Hubungannya Dengan Hak Atas Tanah Terkait Dengan Pesamuan Agung III Tahun 2010' (2019) 2 Kertha Widya Jurnal Hukum.

Komari, 'Eksistensi Hukum Waris Di Indonesia: Antara Adat Dan Syariat' (2015) 17 Asy-Syari'ah.

Victor Imanuel W. Nalle, 'Pembaharuan Hukum Waris Adat Dalam Putusan Pengadilan' (2018) 30 Mimbar Hukum. 
Dinta Febriawanti: Dinamika Hukum Waris...

\section{Tesis}

Wayan P. Windia, 'Sistem Pewarisan Menurut Hukum Adat Bali' (Universitas Udayana 2017).

\section{Laman}

Haniam Maria, 'Mengenal Sistem Kekerabatan Patrilineal Dan Matrilineal' (Kompasiana, 2014) <https://www.kompasiana.com/amp/honey95t/ mengenal-sistem-kekerabatan-patrilineal-dan-matrilineal_54fd224fa333110 43d50f8b7> accessed 11 April 2020.

How to cite: Dinta Febriawanti dan Intan Apriyanti Mansur, 'Dinamika Hukum Waris Adat di Masyarakat Bali Pada Masa Sekarang' (2020) Vol. 3 No. 2 Media Iuris. 